\title{
Angiotensin antagonists could increase urine production and drinking in order to decrease renal problems in diabetes and hypertension
}

\author{
Hypertension Research (2010) 33, 88; doi:10.1038/hr.2009.177; published online 23 October 2009
}

I was very interested to read the recent commentary by Sofue and Kiyomoto ${ }^{1}$ in the journal entitled 'Angiotensin II receptor blocker is a renoprotective remedy for metabolic syndrome', which refers to two articles on the same subject to be published at the same time. These are interesting articles but appear to have missed the point as far as basic physiology is concerned. There have been some publications showing that in mice knock-out of either the angiotensin receptor ${ }^{2,3}$ or the renin gene ${ }^{4}$ generates animals that produce copious amounts of urine and therefore drink appropriately increased volumes of water in compensation. Under normal circumstances this would increase the volume flow through the kidneys, which could lead to an increase in kidney function. Now the question is, would inhibition of the reninangiotensin system have the same effects?

Recently, a letter has been published ${ }^{5}$ about the use of blockers of the renin-angiotensin system and obesity. It was suggested that the observed increase in water drinking in response to the use of an inhibitor of the angiotensin-converting enzyme was responsible for the decrease in weight of the obese animals. An increased drinking response has been observed in several studies now in rats and mice using either inhibition or 'knockout' of the renin-angiotensin system in obese animals. An increased fluid intake could be assumed to help renal dysfunction as well. In a response to a clinical trial using the angiotensin receptor antagonist Candesartan and looking at the renal function of diabetic patients, it was suggested that increased drinking could induce decreases in microalbuminuria. ${ }^{6}$

This is all part of the normal physiological responses to manipulation of the renin-angiotensin system, and therefore I would like to suggest that water consumption and urine excretion be monitored and published in all future animal studies on the use of drugs that block the renin-angiotensin system.

$$
\begin{array}{r}
\text { Simon N Thornton }{ }^{1,2} \\
{ }^{1} \text { Université Henri Poincaré, } \\
\text { Nancy Université, Nancy, France and }
\end{array}
$$

${ }^{2}$ INSERM, U961, Vandoeuvre les Nancy, France E-mail: Simon.Thornton@scbiol.uhp-nancy.fr

\footnotetext{
1 Sofue T, Kiyomoto H. Angiotensin II receptor blocker is a renoprotective remedy for metabolic syndrome. Hypertens Res 2009; 32: 735-737.

2 Li XC, Shao Y, Zhuo JL. AT1a receptor knockout in mice impairs urine concentration by reducing basal vasopressin levels and its receptor signaling proteins in the inner medulla. Kidney Int 2009; 76: 169-177.

3 Mangrum AJ, Gomez RA, Norwood VF. Effects of AT(1A) receptor deletion on blood pressure and sodium excretion during altered dietary salt intake. Am J Physiol Renal Physiol 2002; 283: F447-F453.

4 Takahashi N, Lopez ML, Cowhig Jr JE, Taylor MA, Hatada T, Riggs E, Lee G, Gomez RA, Kim HS, Smithies 0 . Ren 1c homozygous null mice are hypotensive and polyuric, but heterozygotes are indistinguishable from wild-type. J Am Soc Nephrol 2005; 16: 125-132.

5 Thornton SN, Even PC, van Dijk G. Hydration increases cell metabolism. Int J Obes (Lond) 2009; 33: 385.

6 Thornton SN. Stimulated drinking could induce decreases in microalbuminuria of diabetic patients. Ann Intern Med 2009; e-letter (http://www.annals.org/ cgi/eletters/0000605-200907070-00122v1).
} 